\title{
Designer Receptors Enhance Memory in a Mouse Model of Down Syndrome
}

\author{
Ashley M. Fortress, ${ }^{1 \star}$ Eric D. Hamlett, ${ }^{1 \star}$ Elena M. Vazey, ${ }^{1}$ Gary Aston-Jones, ${ }^{1}$ Wayne A. Cass, ${ }^{3}$ Heather A. Boger, ${ }^{1}$ \\ and Ann-Charlotte E. Granholm ${ }^{1,2}$ \\ ${ }^{1}$ Department of Neurosciences and ${ }^{2}$ Center on Aging, Medical University of South Carolina, Charleston, South Carolina 29425, and ${ }^{3}$ Department of \\ Anatomy and Neurobiology, University of Kentucky College of Medicine, Lexington, Kentucky 40506
}

\begin{abstract}
Designer receptors exclusively activated by designer drugs (DREADDs) are novel and powerful tools to investigate discrete neuronal populations in the brain. We have used DREADDs to stimulate degenerating neurons in a Down syndrome (DS) model, Ts65Dn mice. Individuals with DS develop Alzheimer's disease (AD) neuropathology and have elevated risk for dementia starting in their 30s and 40s. Individuals with DS often exhibit working memory deficits coupled with degeneration of the locus coeruleus (LC) norepinephrine (NE) neurons. It is thought that LC degeneration precedes other AD-related neuronal loss, and LC noradrenergic integrity is important for executive function, working memory, and attention. Previous studies have shown that LC-enhancing drugs can slow the progression of $\mathrm{AD}$ pathology, including amyloid aggregation, oxidative stress, and inflammation. We have shown that LC degeneration in Ts65Dn mice leads to exaggerated memory loss and neuronal degeneration. We used a DREADD, hM3Dq, administered via adeno-associated virus into the LC under a synthetic promoter, PRSx8, to selectively stimulate LC neurons by exogenous administration of the inert DREADD ligand clozapine- $N$-oxide. DREADD stimulation of LC-NE enhanced performance in a novel object recognition task and reduced hyperactivity in Ts65Dn mice, without significant behavioral effects in controls. To confirm that the noradrenergic transmitter system was responsible for the enhanced memory function, the NE prodrug L-threo-dihydroxyphenylserine was administered in Ts65Dn and normosomic littermate control mice, and produced similar behavioral results. Thus, NE stimulation may prevent memory loss in Ts65Dn mice, and may hold promise for treatment in individuals with DS and dementia.
\end{abstract}

Key words: designer receptors; Down syndrome; hippocampus; locus coeruleus; neurodegeneration; noradrenergic

\section{Introduction}

Down syndrome (DS) is the most prevalent intellectual disability with an incidence of 1 in 800 live births with $>250,000$ people affected in the United States (Zigman, 2013). Individuals with DS exhibit high comorbidity with Alzheimer's disease (AD; Nelson et al., 2005; Krinsky-McHale et al., 2008; Glasson et al., 2014) and AD neuropathology (Wisniewski et al., 1985). DS-related AD (DS-AD) encompasses classic AD hallmarks including microglial activation, $\beta$-amyloid plaques (Head et al., 2001), and neurofibrillary tangles (Stoltzner et al., 2000), which lead to progressive neurodegeneration of basal forebrain cholinergic neurons, locus ceruleus (LC) neurons, and hippocampal neurons (Granholm et

\footnotetext{
Received June 30, 2014; revised Sept. 26, 2014; accepted 0ct. 29, 2014.

Author contributions: H.A.B. and A.-C.E.G. designed research; A.M.F., E.D.H., E.M.V., and W.A.C. performed research; E.M.V. and G.A.-J. contributed unpublished reagents/analytic tools; A.M.F., W.A.C., and H.A.B. analyzed data; E.D.H., H.A.B., and A.-C.E.G. wrote the paper.

This work was supported by Grant DSADIIP-13-284845 from the Alzheimer's Association and a grant from the NIH (AG012122). We thank Alfred Moore, Claudia Umphlet, and Laura Columbo for excellent technical assistance.

*A.M.F. (who performed the initial experiments with designer receptors exclusively activated by designer drugs and L-DOPS) and E.D.H. (who completed the study, including additional control experiments, cell counting of transfected cells, and confocal microscopy) have shared first-authorship.

The authors declare no competing financial interests.

Correspondence should be addressed to Dr. Ann-Charlotte E. Granholm, Department of Neurosciences, Medical University of South Carolina, 173 Ashley Avenue, BSB Suite 403, Charleston, SC 29425. E-mail: granholm@musc.edu. DOI:10.1523/JNEUROSCI.2658-14.2015

Copyright $\odot 2015$ the authors $\quad 0270-6474 / 15 / 351343-11 \$ 15.00 / 0$
}

al., 2000; Hunter et al., 2004; Salehi et al., 2009; Lockrow et al., 2011; Schliebs and Arendt, 2011). The average lifespan of individuals with DS has increased lately due to improved healthcare (Zigman, 2013). There are currently no successful therapeutic strategies to prevent DS-associated AD (Glasson et al., 2014; Iulita et al., 2014). Therefore, the development of therapeutic or preventive agents for comorbid symptoms of $\mathrm{AD}$ is paramount to the highly susceptible DS population.

The LC nucleus is the main source of norepinephrine (NE) to the hippocampus (Loy et al., 1980) and is a critical modulator of hippocampal and frontal cortex synaptic plasticity (Stanton and Sarvey, 1985; Bramham et al., 1997; Morris et al., 2003; Vazey and AstonJones, 2012). The LC-neurons degenerates early in $\mathrm{AD}$ and in DS-AD (Mann et al., 1986; German et al., 1992). LC-NE lesions, using the selective NE neurotoxin DSP-4 [N-(2-chloroethyl)- $\mathrm{N}$ ethyl-2-bromobenzylamine], leads to aggravated amyloid pathology in $\mathrm{AD}$ mouse models (Kalinin et al., 2007), and we have demonstrated that $\mathrm{AD}$ neuropathology and cognitive impairment are aggravated by LC-NE lesions in a mouse model of DS, the Ts65Dn mouse (Lockrow et al., 2011). Ts65Dn mice have a triplication of the centromere and proximal end of chromosome 17 , and the distal end of mouse chromosome 16 , syntenic to $60 \%$ of genes triplicated in Human DS (Hsa21; Davisson et al., 1990). Ts65Dn mice exhibit accelerated atrophy and degeneration of basal forebrain, hippocampal, and LC-NE neurons, in addition to accelerated memory loss in 
several cognitive domains and hyperactivity (Escorihuela et al., 1995; Lockrow et al., 2012; Ruparelia et al., 2013). Treatment with the NE precursor L-threo-dihydroxyphenylserine (L-DOPS) enhanced contextual learning in Ts65Dn mice (Salehi et al., 2009). However, a direct connection between LC signaling and hippocampaldependent behavior can provide additional information by using a targeted approach such as the designer receptors used here.

Targeted expression of genetically modified designer receptors exclusively activated by designer drugs (DREADDs) is an innovative tool that can be used to enhance neuronal activity (Vazey and Aston-Jones, 2014) and discrete neuronal populations (Clark et al., 2000; Nawaratne et al., 2008; Alexander et al., 2009; Pei et al., 2010). We used DREADDs in LC-NE neurons under control of the synthetic PRSx8 promoter for dopamine- $\beta$ hydroxylase (DBH; Vazey and Aston-Jones, 2014) to limit distribution of the DREADDs to LC-NE neurons. Stimulation of the inserted DREADDs using clozapine- $N$-oxide $(\mathrm{CNO})$ gave rise to the normalization of memory behavior in Ts65Dn mice, therefore introducing a novel method for demonstrating the influence of discrete neuronal populations on behavior.

\section{Materials and Methods}

Animals. Male Ts65Dn mice and normosomic (NS) littermate controls were obtained from The Jackson Laboratory. All mice were 11-13 months of age before treatment. Ts65Dn mice are partially trisomic for a segment of murine chromosomes 16 and 17, as described in detail by Davisson et al. (1990), and have been used by our laboratory routinely (Lockrow et al., 2009, 2010; for review, see Lockrow et al., 2012). All mice were single housed, received food and water ad libitum, and were maintained on a $12 \mathrm{~h}$ light/dark cycle. All experimental procedures were approved by the Institutional Animal Care and Use Committee of the Medical University of South Carolina in accordance with the guidelines described in the National Institutes of Health Guide for the Care and Use of Laboratory Animals.

Intracranial microinjection of adeno-associated virus PRSx8 hM3Dq. PRSx8-hM3Dq HA vector $\left(2 \times 10^{12}\right.$ transduction units/ $\mu$ l; Vazey and Aston-Jones, 2014) was cloned and packaged with adeno-associated virus (AAV) 2/9 serotype at the University of Pennsylvania Vector Core. The PRSx8 promoter (Hwang et al., 2001) was used to drive the expression of the hM3Dq designer receptor with a C-terminal HA1.1 tag for identification (Armbruster et al., 2007; Alexander et al., 2009; provided by Bryan Roth, University of North Carolina, Chapel Hill, NC). NS ( $n=$ 7) and Ts65Dn $(n=6)$ male mice were anesthetized with ketamine/ xylazine $(120 / 6 \mathrm{mg} / \mathrm{kg}$, i.p.) and given a long-acting local anesthetic in the skin overlying the injection site (bupivacaine, $1 \mathrm{mg} / \mathrm{kg}$, s.c.) before surgery. Anesthetized mice were placed in a rodent stereotaxic apparatus with a mouse adaptor, and intracranial injections of AAV were delivered bilaterally into the LC via a Hamilton syringe at the following stereotaxic coordinates: -5.34 anteroposterior, -2.5 dorsoventral, \pm 1.0 mediolateral from bregma (Paxinos and Franklin, 2004). AAV was delivered at a rate of $\sim 0.1 \mu \mathrm{l} / \mathrm{min}$ over $10 \mathrm{~min}$ for a total volume of $1.0 \mu \mathrm{l}$ per injection site. After microinjection, the syringe was left in place for $10 \mathrm{~min}$ to limit diffusion into the injection track. Animals were then sutured, removed from the apparatus, and monitored for full recovery before returning to disposable cages housed in a biological safety level 2 room. Behavioral testing began $20 \mathrm{~d}$ after the AAV injections.

Spontaneous locomotor activity. All mice in the hM3Dq study were observed for overall locomotor activity to monitor changes in motor activity that may have resulted from AAV injection and/or CNO stimulation of the DREADDs. Spontaneous activity was measured using the Digiscan Animal Activity Monitor system, and horizontal and vertical activity were collected as described previously (Boger et al., 2006; Lockrow et al., 2011). Briefly, mice were placed in a darkened testing chamber and allowed to move freely through photo beam breaks in the $x$-, $y$-, and $z$-axes for $1 \mathrm{~h}$ with sampling at 5 min intervals. Data were analyzed using Digiscan software.

Novel object recognition task. We have previously used the novel object recognition task (NORT) in Ts65Dn mice, showing a significant deficit in discrimination of novel versus familiar objects, after both a short and long delay interval (Lockrow et al., 2011). Briefly, mice were individually placed in the testing arena ( $40 \mathrm{~cm}$ long $\times 40 \mathrm{~cm}$ wide $\times 30 \mathrm{~cm}$ high) for a period of $5 \mathrm{~min}$ with no objects present for habituation purposes. On the next day of testing, mice were placed in the chamber with two identical objects placed in the northeast and northwest corners $(\sim 2$ inches from the side of the chamber and 6 inches apart). Interactions with both objects were recorded for 15 min with a digital video camera mounted overhead. After a 90 min delay, mice were placed in the chamber with the following two objects: a familiar object from the preceding set; and a novel object. Interactions with both objects were recorded for $15 \mathrm{~min}$. The spatial location for the objects remained the same throughout testing. Videos were scored for both the frequency and duration of time with each object by a blind observer. For each study, the following two dependent measures were calculated: the percentage of time spent with the novel object and the discrimination index (DI; Lockrow et al., 2009, 2011). The DI represents the net time spent with the novel object relative to the total time spent with both objects. This task was the primary behavioral outcome for the two studies, and was used for both the DREADD and the L-DOPS studies to compare behavioral results between the two different treatment paradigms (see Figs. 3, 4, respectively).

Spontaneous alternation task. The spontaneous alternation plus maze is an index of hippocampus-dependent spatial working memory (Savage et al., 2003), and mouse models of DS show deficits in this task (Kaur et al., 2014). The four-arm spontaneous alternation task (SAT) is nonappetitive and nonaversive. Mice were placed in the center of the maze and recorded by an unbiased observer while they were allowed to explore all four equally spaced arms at random for a total of $12 \mathrm{~min}$. An entry into an arm was recorded when all four paws entered an arm. After the completion of testing, the mouse was returned to its home cage. The percentage of alternations was calculated as described by others (Stefani and Gold, 2001). Briefly, the number of alternations was calculated by allowing only one repeat entry in a series of five entries, which was analyzed in a series of overlapping quintuplets. The percentage of alternation is the number of alternations made relative to the total possible number of alternations, expressed as a percentage. For example, 1432341342 would be four of six possible alternations (number of entries, four; 67\%).

DREADD $h M 3 D q$ study design. Ts65Dn mice $(n=6)$ and littermate control NS mice $(n=7)$ were tested $20 \mathrm{~d}$ after intracranial surgery to allow receptor translation/trafficking. Mice received $0.3 \mathrm{mg} / \mathrm{kg} \mathrm{CNO}$ (Sigma) intraperitoneally in sterile water or sterile water alone [vehicle (VEH) ], 5 min before the start of behavioral testing, according to previously published protocols (Alexander et al., 2009; Vazey and AstonJones, 2014). Mice received an injection with either CNO $(0.3 \mathrm{mg} / \mathrm{kg})$ or $\mathrm{VEH}$ in a randomized crossover design. Following CNO dosing, mice were placed in locomotor activity chambers for $1 \mathrm{~h}$ immediately before habituation in the NORT arena. The following day, all mice were given the respective injections again and were evaluated in the NORT memory task. After $2 \mathrm{~d}$, to ensure CNO clearance, the treatments were switched for each mouse followed by habituation and NORT memory testing. Mice were killed, and the brains were rapidly extracted within 1 week of behavioral testing (see Fig. 2A, schematic).

L-DOPS study design. Ts65Dn mice (L-DOPS, $n=6$; VEH, $n=6$ ) and littermate control NS mice (L-DOPS, $n=6$; VEH, $n=5$ ), which were male and 11 months of age, were injected with L-DOPS plus carbidopa (L-DOPS) or with carbidopa alone (VEH) for 2 weeks every other day (see Fig. 4A, experimental design). Carbidopa (Chelsea Therapeutics International, Ltd.) was manufactured in a solution of $0.2 \mathrm{M} \mathrm{HCl}$ containing $2 \mathrm{mg} / \mathrm{ml}$ ascorbic acid to prevent oxidation and was coadministered to decrease peripheral sympathetic activation (see also Kato et al., 1987; Salehi et al., 2009). The ascorbic acid was neutralized immediately before injection with a $6.6 \mu \mathrm{l} / \mathrm{ml} 10 \mathrm{M} \mathrm{NaOH}$ solution to reach a $\mathrm{pH}$ of 7.0. Mice received subcutaneous injections of either carbidopa at $0.125 \mathrm{mg} / \mathrm{g}$ body weight at an injection volume of $0.02 \mathrm{ml} / \mathrm{g}$ or carbidopa plus L-DOPS (200 mg/kg; Chelsea Therapeutics International, Ltd.). On test days, injections were made $5 \mathrm{~h}$ before tests since the concentration of L-DOPS peaks in rodents after $5 \mathrm{~h}$ in vivo (Kato et al., 1987). After 2 weeks of L-DOPS treatment, all subjects were evaluated by NORT and an SAT 
A
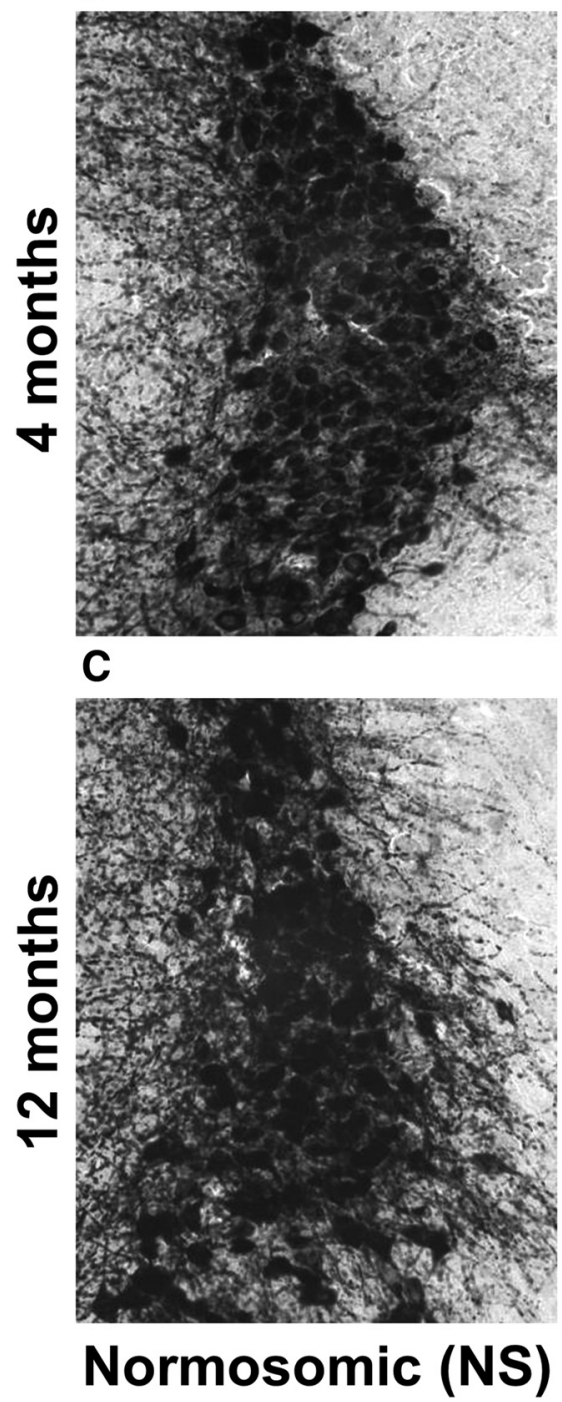

B

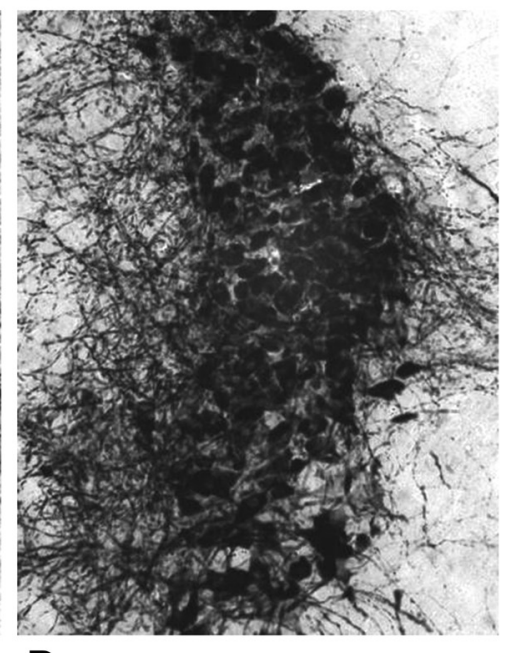

D

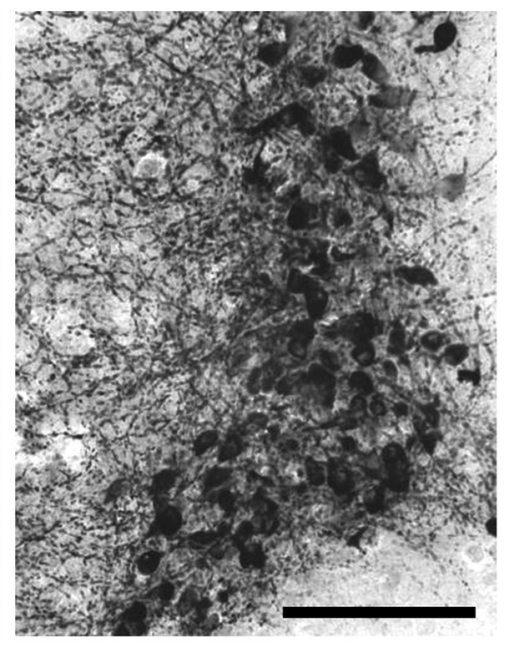

\section{Ts65Dn (TS)}

Figure 1. TH immunostaining in the LC-NE region of Ts65Dn mice and NS mice at 4 and 12 months of age. $A, B$, At 4 months of age, there was no difference in terms of TH staining density between NS (A) and Ts65Dn (B) mice. $\boldsymbol{C}, \boldsymbol{D}$, However, at 12 months of age, there was a marked reduction in TH-immunoreactive fiber density and cell-packing density in Ts65Dn mice (D), compared with NS mice (C). TH-positive LC cell bodies had observable degenerative morphology, including a pyknotic nucleus and reduced intracellular TH staining in Ts65Dn mice (D). Representative images taken at 10× magnification. Scale bar, $200 \mu \mathrm{m}$.

according to our previous protocols (Lockrow et al., 2011, 2012) and as described in detail above.

Tissue preparation. Within 1 week of behavioral testing, all mice were killed using an overdose of isoflurane, and the brains were rapidly dissected. Tissues were divided for HPLC or immunohistochemistry according to our standard procedures (Boger et al., 2011; Lockrow et al., 2011). The right frontal cortex and right hippocampus were dissected for catecholamine tissue levels, placed into preweighed tubes, weighed for tissue weight, snap frozen on dry ice, and stored at $-80^{\circ} \mathrm{C}$ until use. The remaining brain tissue was placed into $4 \%$ paraformaldehyde for $48 \mathrm{~h}$ for immersion fixation, then placed into $30 \%$ sucrose in PBS for at least $72 \mathrm{~h}$ before sectioning at $40 \mu \mathrm{m}$ on a Microm cryostat (Thermo Fisher Scientific) for immunohistochemistry.

Immunostaining. The hippocampus and the pontine region containing the LC were sectioned at $40 \mu \mathrm{m}$ and processed for immunohistochemical analyses, as described previously (Lockrow et al., 2011). Briefly, series of every sixth section were blocked in 10\% NGS in TBS-Triton X-100 and incubated with anti- $\beta 1$ receptor (1:500; Santa Cruz Biotechnology), or anti-tyrosine hydroxylase (TH; 1:1000; Pel-Freeze) and anti-HA antibodies (1:1000; Cell Signaling Technologies) overnight at room temper- ature. The sections processed for fluorescence microscopy (HA and TH immunohistochemistry) were then incubated for $1 \mathrm{~h}$ with secondary antibodies directed against the appropriate species, conjugated with TRITC or FITC, respectively (1:200; Jackson ImmunoResearch). Sections stained for the $\beta 1$ receptor or TH diaminobenzidine (DAB) staining (Fig. 1) were incubated with biotinylated anti-rabbit secondary antibodies, then $\mathrm{ABC}$ solution (Vector Laboratories) followed by development with DAB (Sigma; see Lockrow et al., 2011). The tissue was mounted onto slides, dehydrated, and coverslipped with Permount (Fisher Scientific). All images we captured using a Nikon Eclipse E-600 microscope equipped with a Qcam digital camera.

Densitometry and cell counting. To determine the staining density of $\beta 1$ NE receptors in the hippocampus, a series of every sixth section throughout the rostrocaudal extent of the hippocampus was evaluated. Images were acquired on a Nikon microscope, with settings remaining identical across all image acquisitions. Using the NIS Elements Advanced Research software system (Nikon Instruments), the region of interest was outlined to include the upper and lower blades of the dentate gyrus and lateral border of the granule cell layers in the dentate. The NIS Elements software uses an 8 -bit scaling system (0-256 gray levels). The average staining density in the hippocampus was averaged across all sections per animal (9-12 sections). Background correction was obtained by subtracting the mean of three unstained background measurements on each section from the mean density measurement (Hunter et al., 2003a,b). Confocal laser scanning microscopy (Fluoview BX61, Olympus) was used to generate $3 \mathrm{D}$ images of at least seven randomly distributed sections from the locus ceruleus in both normosomic and Ts65Dn mice. NIS Elements software was used to determine the percentage of HA-labeled THpositive LC neurons based on blind hand counting. Specifically, all TH-positive neurons in the LC (Fig. 2, green fluorescence) were counted in multiple sections from each brain. Thereafter, all TH-immunoreactive neurons colabeled with HA (Fig. 2, red fluorescence) were counted on the same sections, and the data were expressed as the percentage of $\mathrm{TH}$-positive neurons that also contained HA fluorescence (Fig. 2H).

HPLC analysis. Samples were sonicated in $300 \mu \mathrm{l}$ of cold $0.1 \mathrm{M}$ perchloric acid containing dihydroxybenzylamine as an internal standard. They were then centrifuged for $5 \mathrm{~min}$ at $12,000 \times \mathrm{g}$, and the supernatant was filtered through a $0.22-\mu \mathrm{m}$-pore size membrane (Ultrafree Centrifugal Filter, Millipore). The filtrate was then assayed for NE using HPLC, as previously described (Cass et al., 2003). Tissue levels of NE for each mouse in the study were expressed in nanograms per gram wet weight of tissue.

Statistical considerations. One-factor ANOVA was used for comparison between the groups, eliminating the need for multiple pairwise hypothesis tests. A $t$ test was conducted between treated and untreated NS groups (CNO or L-DOPS treated), and no statistical effects of the treatments were observed in any of the outcome measures between the two NS groups (see each figure legend), except in the NE receptors (see Fig. 5). The expected outcome from these studies was therefore directed specifically toward treatment effects in the two Ts65Dn groups, as well as statistical differences between vehicle-treated NS and Ts65Dn groups. 
Following examination of the statistical relationship between treated and untreated NS groups, the two NS groups were collapsed and compared with the two Ts65Dn groups using an ANOVA overall analysis. Tukey's post hoc analysis was used for all post hoc tests to examine statistical patterns that were not specified a priori, and post hoc results were reported with an acceptable $\alpha$ value of $p<0.05$. Pearson product moment correlation (PPMC) was used to determine relationships between behavioral and biochemical data (see Fig. 5). All statistics were performed with GraphPad Prism 6 software (version 6.04), and all data are presented as the mean \pm SEM.

\section{Results}

LC degeneration in Ts65Dn mice

Immunohistochemical assessment of the LC-NE region using $\mathrm{TH}$ antibodies revealed a marked loss of both TH-positive cell bodies and neurites in the LC region in middle-aged Ts65Dn mice compared with NS mice (Fig. 1). The loss of THimmunoreactive neurons in the LC was not observed at earlier ages (4-month-old Ts65Dn and NS mice; Fig. $1 A, B)$. THstained sections in 12-month-old Ts65Dn mice revealed atrophic neurons as well as swollen and dystrophic neurites in the LC (Fig. 1D), and reduced TH staining within neuronal cell bodies. It is established that the LC begins to degenerate as early as 6 months of age in Ts65Dn mice (Salehi et al., 2009), with a significant loss of neurons observed by our group at 12 months of age using unbiased stereological cell counting (Lockrow et al., 2011). The age of mice chosen for the current study was based on the LC-NE cell loss observed at this age.

To determine the transduction efficiency of the vector in LC-NE neurons of the pons, we performed immunostaining of the HA tag included in the viral construct, using double labeling with $\mathrm{TH}$ and HA antibodies (Fig. 2). Five weeks postinjection, robust expression of the HA tag was observed in the LC region using immunofluorescence in both NS (Fig. $2 B-D$ ) and Ts65Dn mice (Fig. $2 E-G$ ). Colabeling of $\mathrm{HA}$ and $\mathrm{TH}$ revealed that an average of $98 \%$ of $\mathrm{TH}$-positive cells in the LC also costained with the HA1.1-tagged DREADD receptor (sampling was performed in 19 sections in five subjects, in both NS and Ts65Dn mice; range of colabeling, 86-100\%; see Fig. 2H). Anterograde $\mathrm{hM} 3 \mathrm{Dq}$ receptor trafficking in axons adjacent to the LC nucleus was observed, suggesting a functional integration of the DREADDs into LC neurons (Fig. 2I, white arrows). The HA-TH double labeling demonstrated that AAV transduction of the DREADD receptors in LC-NE neurons was successful, efficient, and specific to the LC neurons, in both NS and in Ts65Dn mice.

H
A Design
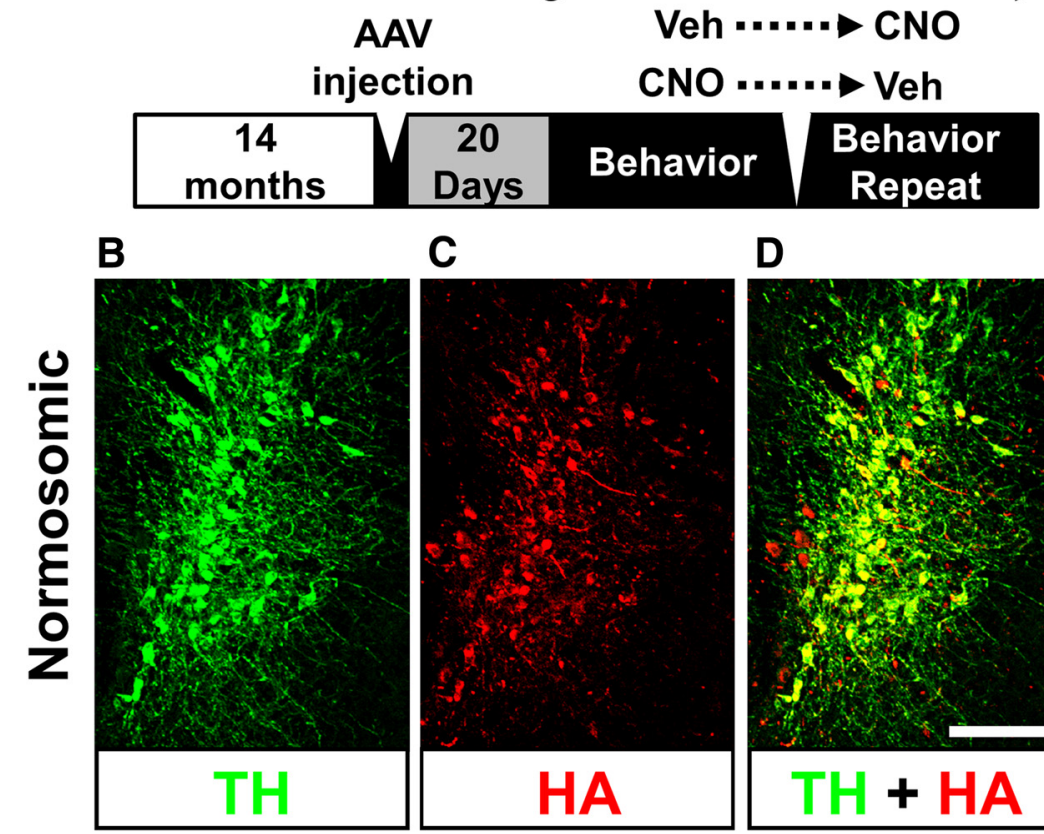

C

D
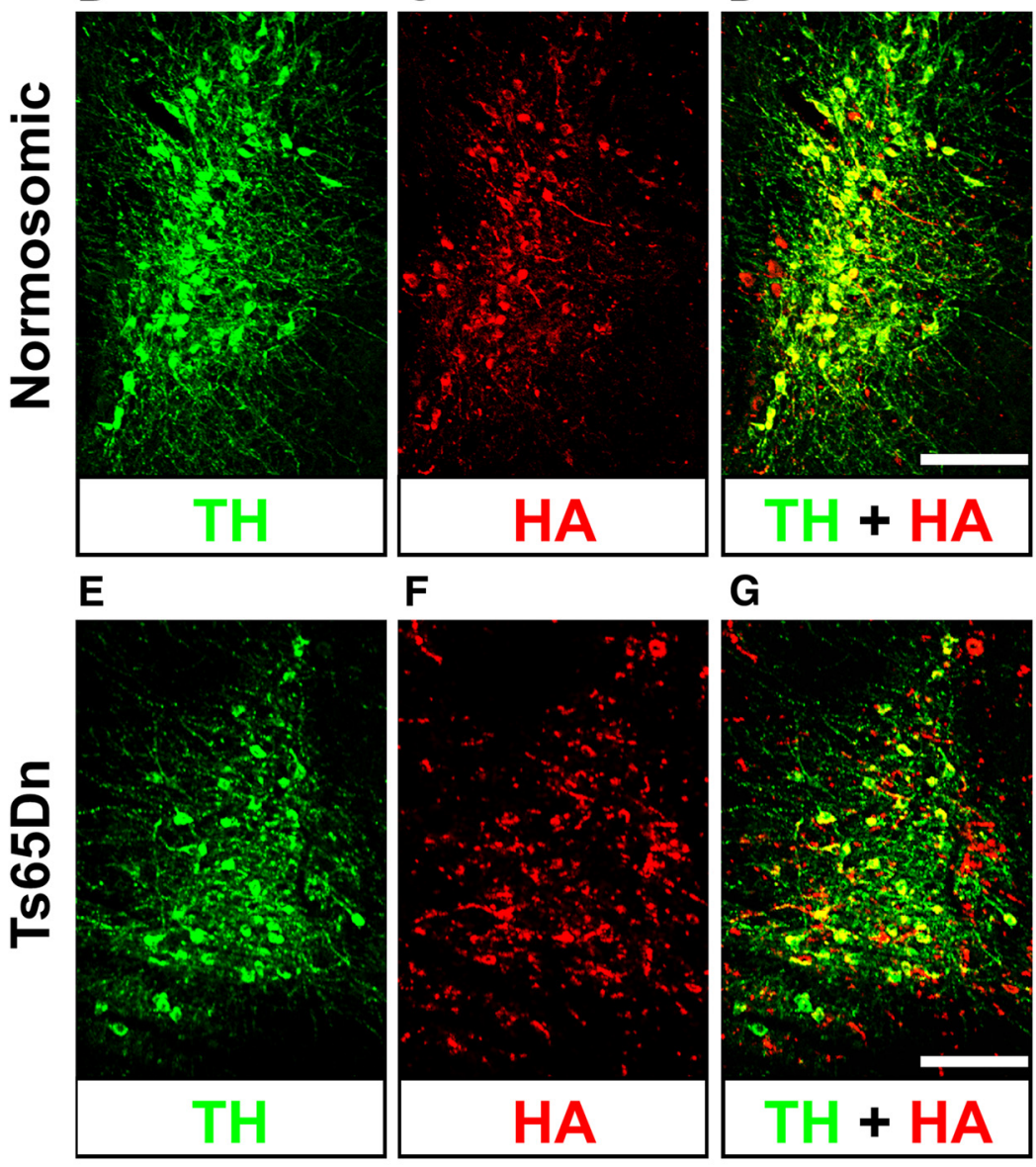

$\mathbf{F}$

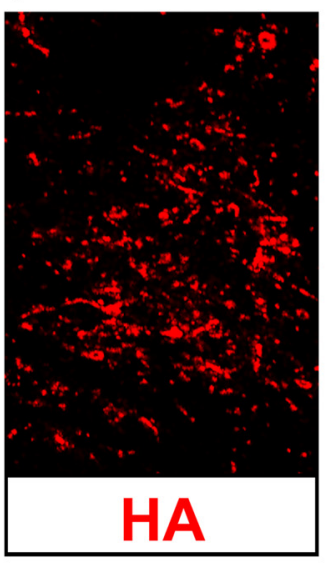

G

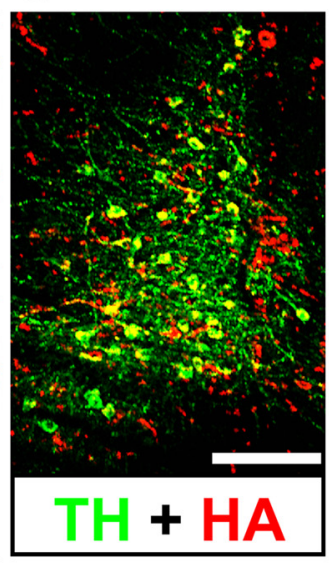

\begin{tabular}{|c|c|c|}
\hline \multicolumn{3}{|c|}{$\begin{array}{c}\text { LC Transduction } \\
\text { Efficiency }\end{array}$} \\
\hline Range & Mean & St.Dev \\
\hline $86-100 \%$ & $98 \%$ & $\pm 3.5 \%$ \\
\hline
\end{tabular}

I

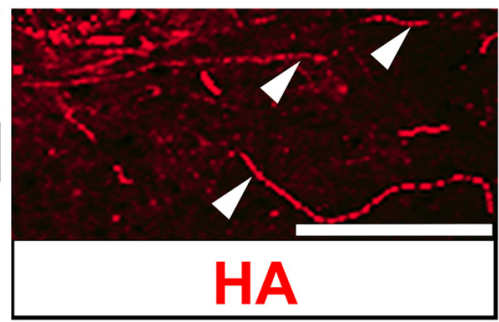

Figure 2. TH and HA immunostaining in the LC. A, Experimental design for the DREADD study. The AAV-HA tag vector was injected via stereotaxic injections into T565Dn or NS mice. Twenty days after surgery, mice were tested for behavior. After a $2 \mathrm{~d}$ washout period, mice were given the opposite treatment in a crossover design. $\boldsymbol{B}-\boldsymbol{D}$, TH immunostaining ( $\boldsymbol{B}$, green), HA staining $(\boldsymbol{C}$, red), and overlay ( $\boldsymbol{D}$, yellow) in a normosomic mouse LC. $\boldsymbol{E}-\boldsymbol{G}, T H(\boldsymbol{E}$, green), HA ( $\boldsymbol{F}$, red), and overlay ( $\boldsymbol{G}$, yellow) in the LC of a Ts65Dn mouse. $\boldsymbol{H}$, Transduction efficiency table, showing range, mean, and SD measured in a total of 19 double-labeled sections. I, FITC-labeled HA immunostaining in the $L C$ region at a higher magnification, with evidence of axonal transport of the DREADD receptors (arrowheads). Scale bars: $\mathbf{D}, \mathbf{G}, 100 \mu \mathrm{m} ; \mathbf{I}, 40 \mu \mathrm{m}$.

DREADD hM3Dq-mediated behavior

Stimulation of the hM3Dq receptor with the pharmacologically inert agent $\mathrm{CNO}$ facilitates neuronal tonic increases in target neurons (Armbruster et al., 2007; Vazey and Aston-Jones, 2014). The same hM3Dq construct used in the current study has re- 
A
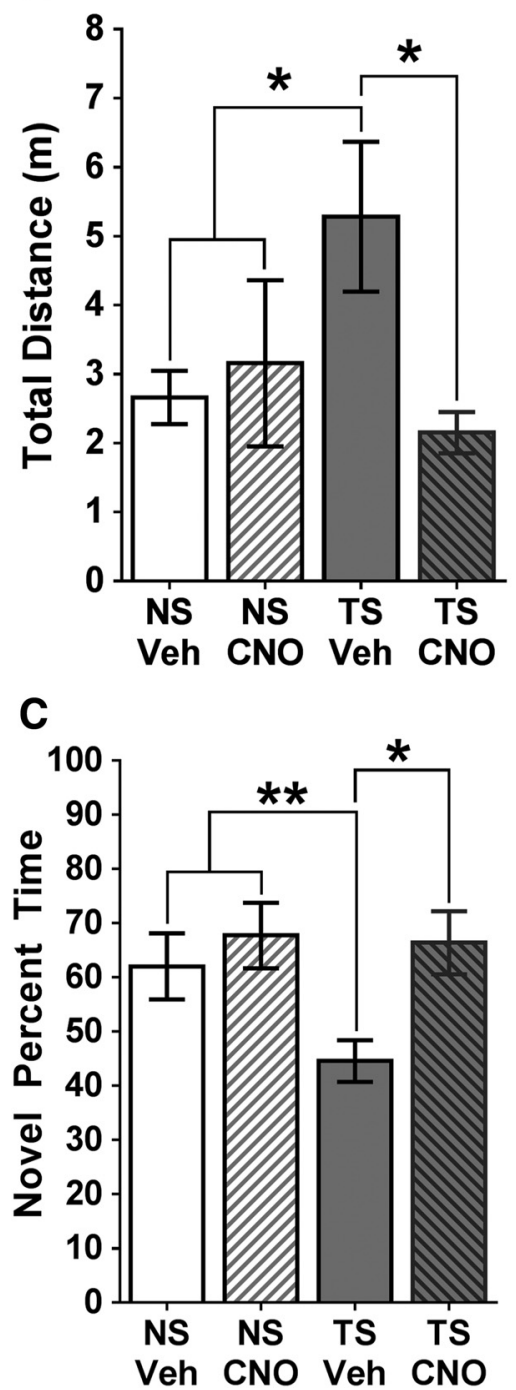

B

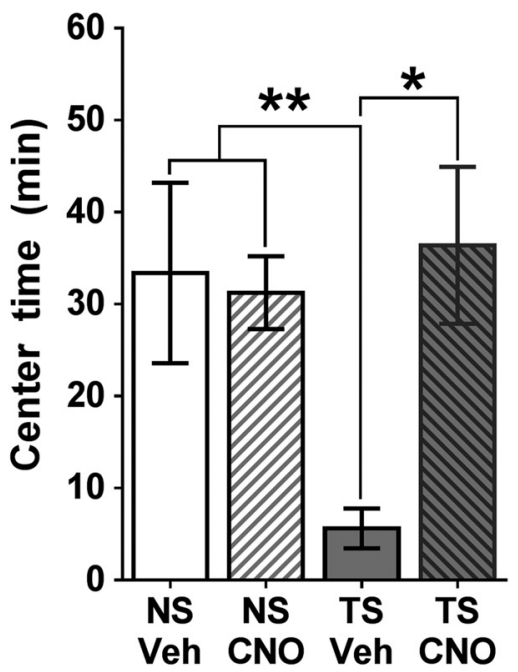

D

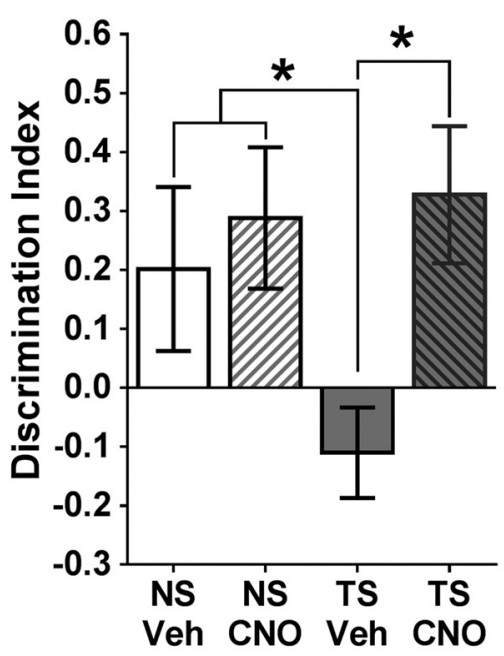

Figure 3. Behavioral outcomes of the DREADD experiment. $\boldsymbol{A}$, Spontaneous locomotion. Vehicle-treated Ts65Dn (TS) mice exhibited a significant increase in the total distance traveled $(\mathrm{m})$, which was attenuated with CNO treatment. $\boldsymbol{B}$, Time spent in the center. Vehicle-treated Ts65Dn mice spent less time in the center of an open-field compared with NS mice, which was reversed with CN0 treatment. C, NORT. Vehicle-treated Ts65Dn mice spent significantly less time with the novel object than NS mice, and this deficiency was normalized after treatment with CN0, with a significant difference between Ts65Dn mice with or without CN0. D, Discrimination index for the NORT. NS mice were significantly more likely to recognize the novel object than vehicle-treated Ts65Dn mice, which were normalized after CNO treatment. Error bars represent the mean \pm SEM. There was no significant difference between the NS VEH and CNO groups for any of these measures. ${ }^{*} p<0.05 ;{ }^{* *} p<0.01$.

cently been used by others in our group to demonstrate increased firing rates of LC neurons (Vazey and Aston-Jones, 2014). Statistical analysis of the two NS groups (with or without CNO injections) revealed that NS mice showed no significant differences in locomotion ( $p=0.673)$, time spent in the center $(p=0.847)$, or object discrimination in the NORT task after hM3Dq activation with CNO ( $p=0.522$ ), as evident from the graphs in Figure $3 A-C$. Based on these findings, the two NS groups have been collapsed for the purpose of examining a priori the effects of trisomy and CNO plus trisomy compared with NS mice.

Because hyperactivity has been observed in the Ts65Dn mouse model and may influence other behavioral components, we first examined the effects of LC hM3Dq stimulation on baseline motor activity in Ts65Dn mice (Fig. 3A). Both NS and Ts65Dn mice without $\mathrm{CNO}$ exhibited spontaneous behavior similar to what we have previously reported for age-matched mice of both karyo- types (see Lockrow et al., 2011), strongly indicating that the AAV injection itself did not give rise to alterations in spontaneous activity. An ANOVA analysis revealed overall statistical differences between the groups $\left(F_{(2,15)}=5.101 ; p=0.0249\right)$, and post hoc analysis (Tukey's test) further revealed that vehicle-treated Ts65Dn mice displayed significantly increased spontaneous activity relative to NS control mice $(p=0.0231)$, revealing hyperactivity in Ts65Dn mice. CNO injections in Ts65Dn mice significantly attenuated hyperactivity, with CNO-treated Ts65Dn mice exhibiting significantly less total activity than vehicletreated Ts65Dn mice (Tukey's test, $p=$ 0.0111). CNO-treated Ts65Dn mice were not significantly different in overall activity than NS control mice $(p=0.4508)$, suggesting that stimulating $\mathrm{hM} 3 \mathrm{Dq}$ receptors restored spontaneous activity to levels observed in NS mice. Next, the time spent in the center of the activity arena was evaluated, and an overall ANOVA also revealed significant group differences for this measure $\left(F_{(2,15)}=5.315 ; p=\right.$ 0.0243; Fig. 3B). Interestingly, although vehicle-treated Ts65Dn mice were significantly more active than NS mice, they spent significantly less time in the center of the open field arena relative to NS mice, as revealed using post hoc analysis (Fig. 3B; $p=0.0088)$. However, Ts65Dn mice treated with $\mathrm{CNO}$ spent significantly more time in the center of the open field arena compared with nontreated Ts65Dn mice ( $p=0.0291)$, with times spent in the center that were comparable to those observed in NS mice, suggesting that stimulating $\mathrm{LC} \mathrm{hM} 3 \mathrm{Dq}$ receptors reduced anxiety-like behavior and hyperactivity in Ts65Dn mice. The spontaneous locomotion data are the first to demonstrate that hM3Dq/CNO stimulation of LC-NE can acutely reduce hyperactivity in the Ts65Dn mouse model, without exerting any effects on either total activity or on time spent in the center in NS mice transfected with the DREADDs.

\section{Novel object recognition task}

We first evaluated whether or not hM3Dq-mediated stimulation of the LC could alleviate memory deficits in Ts65Dn mice at an age when LC degeneration and cognitive impairment are both apparent (Lockrow et al., 2011; Fig. 1). Twenty days after AAV injection, we tested NS and Ts65Dn in the novel object recognition task. All mice received an intraperitoneal injection of either $\mathrm{CNO}$ or vehicle on each day of the task, 5 min before testing. To determine whether mice had a preference for the novel object, we first calculated the percentage of time spent with the novel object. A Student's $t$ test between the two NS groups revealed that there was no significant difference between $\mathrm{CNO}$ - or vehicle-treated NS mice in terms of discrimination index in NORT $(p=0.6470$; 
Fig. 3D); therefore, the two NS groups were collapsed for further comparison with the Ts65Dn groups. An overall ANOVA between NS mice versus the two Ts65Dn groups revealed group differences for time spent on the novel object between Ts65Dn mice with or without CNO treatment and NS mice $\left(F_{(2,21)}=\right.$ $4.623 ; p=0.0231)$. Tukey's post hoc analysis revealed that the mean time spent with the novel object was significantly less in vehicle-treated Ts65Dn mice compared with NS mice (Fig. $3 C ; p=0.048$ ). Importantly, the AAV injection per se did not appear to exert any behavioral effects, since non-AAV-injected NS and Ts65Dn control mice in the L-DOPS experiment (Fig. $4 B, C$ ) exhibited close to identical performance in both the time on novel object (Fig. $4 B$ ) and discrimination index (Fig. $4 C$ ) as the AAV-injected NS and Ts65Dn mice with vehicle in the DREADD experiment. The CNO injection reversed the NORT deficits in Ts65Dn mice, as CNO-treated Ts65Dn mice exhibited a significant increase in the percentage of time spent with the novel object compared with vehicle-treated Ts65Dn mice $(p=0.029)$. Importantly, CNO-treated Ts65Dn mice were able to discriminate the novel object just as effectively as NS mice $(p=0.8675$; Fig. $3 D)$, suggesting that hM3q LC stimulation restored cognition to levels observed in NS mice.

Because the percentage of time spent with the novel object does not readily indicate behavioral perseverance, we also calculated the DI for each group of mice. An overall ANOVA of DI values for each group revealed overall statistical differences between the groups $\left(F_{(2,21)}=3.821\right.$; $p=0.0414)$. No statistical difference in DI was observed between the vehicle- and CNO-treated NS mice $(p=0.6470)$. Vehicle-treated Ts65Dn mice were significantly less likely to discriminate the novel object from the familiar one, compared with NS mice $(p=0.0238)$, as indicated by the negative DI value. The inability to discriminate the familiar object observed in vehicle-treated Ts65Dn mice was reversed by $\mathrm{CNO}$, as CNO-treated Ts65Dn mice significantly preferred the novel object compared with the familiar object during the discrimination phase ( $p=$ 0.0267). Collectively, these findings suggest that hM3Dq/CNO-mediated LC activation can enhance cognition in middle-aged Ts65Dn mice by reducing delayed working memory deficits and reducing behavioral perseverance. Agematched Ts65Dn and NS control mice without AAV injection surgery included in the L-DOPS experiment (see below) exhibited close to identical behavioral performance compared with Ts65Dn and NS mice with injections of AAV plus vehicle,
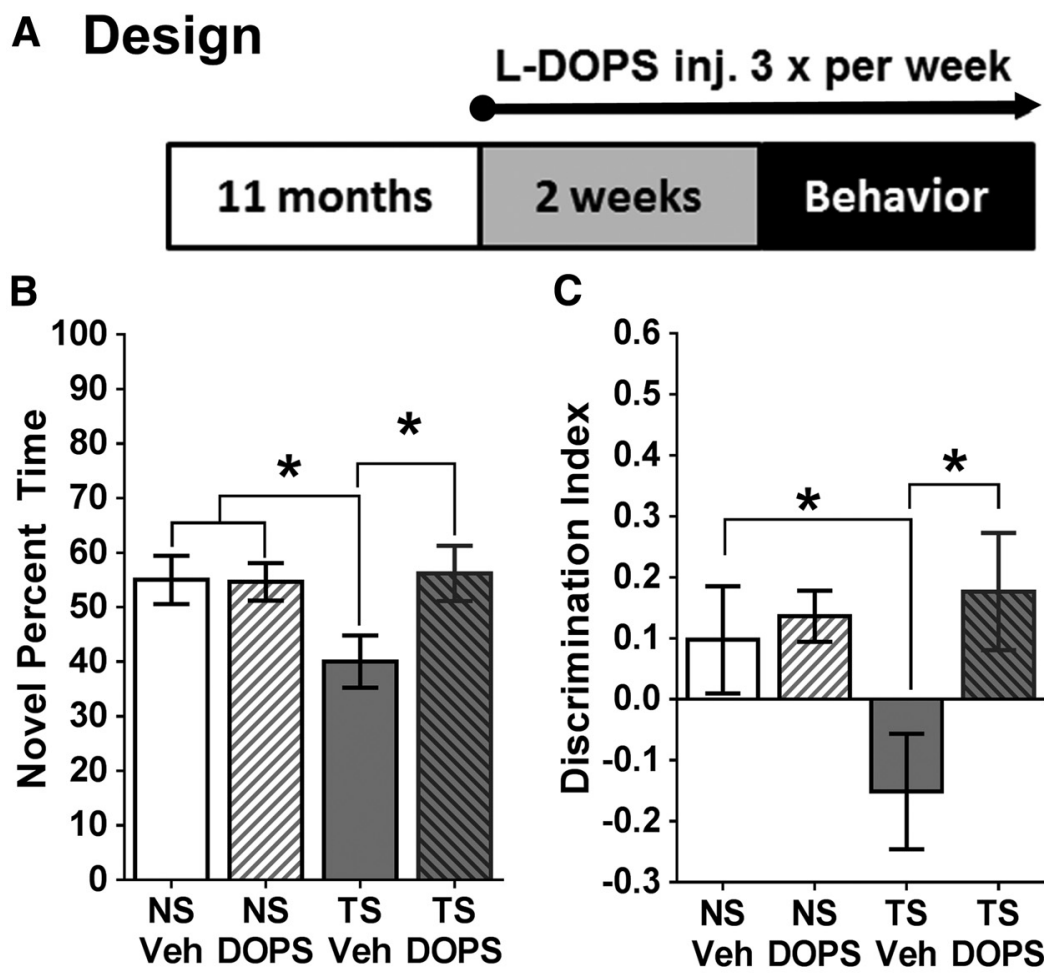

C
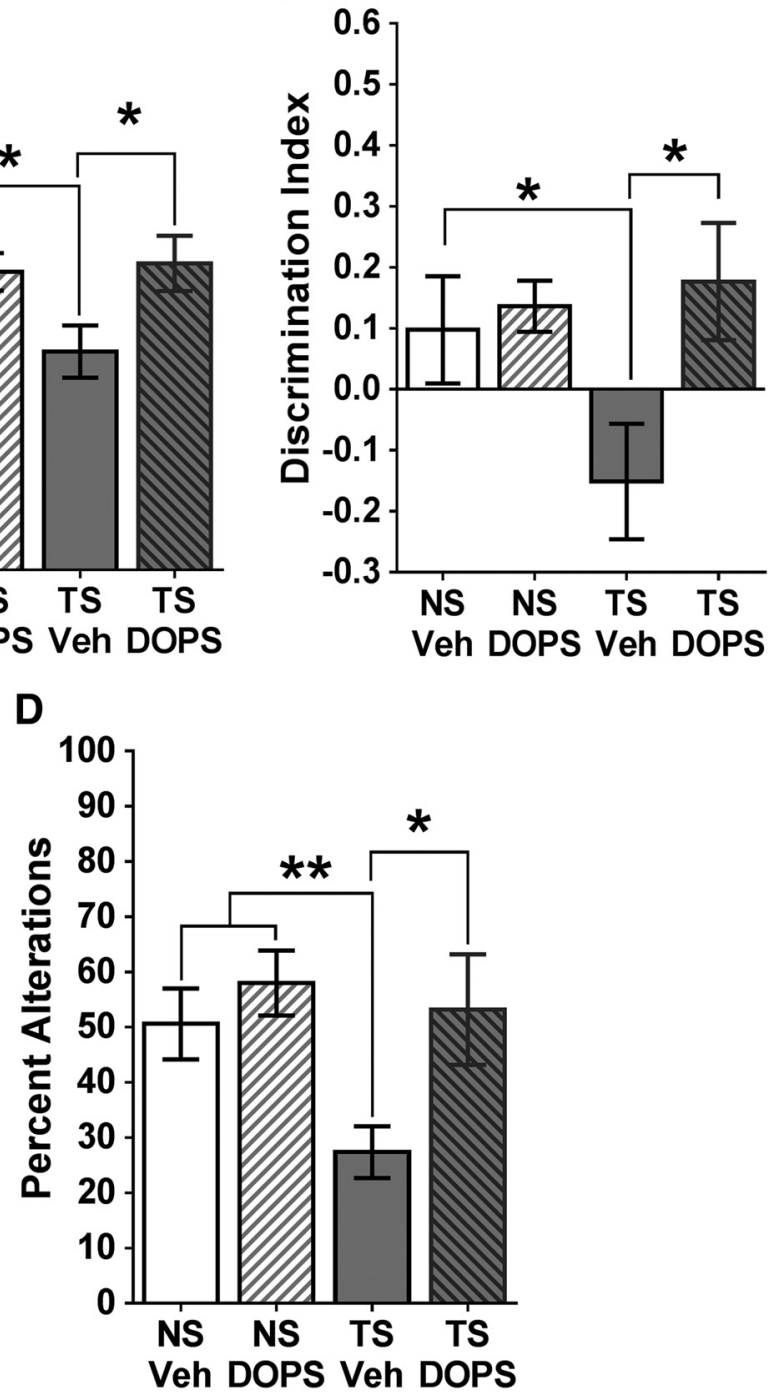

Figure 4. Behavioral outcomes of the L-DOPS experiment. $\boldsymbol{A}$, Experimental design. Ts65Dn (TS) and NS mice received L-DOPS injections every second day for 2 weeks before behavioral testing, and every day during the behavioral testing. $\boldsymbol{B}$, NORT. Vehicletreated Ts65Dn mice spent significantly less time with the novel object than NS mice; however, L-DOPS-treated Ts65Dn mice spent significantly more time with the novel object than vehicle-treated TS mice. C, Discrimination index. Vehicle-treated Ts65Dn mice exhibited a significant decrease in their ability to detect a novel object compared with NS mice, but this impairment was reversed with L-DOPS treatment. D, Spontaneous alternation task. Vehicle-treated Ts65Dn mice made significantly fewer alternations than NS mice; however, spatial working memory was restored in TS65Dn mice after L-DOPS treatment, with a significant difference detected between Ts65Dn mice with and without L-D0PS. As can be seen in the bar graphs, there was no significant difference between the L-DOPS- and VEH-treated NS groups for any of these behavioral measures. inj., Injection. Error bars represent the mean \pm SEM. ${ }^{*} p<0.05 ;{ }^{* *} p<0.01$.

strongly suggesting that the AAV injections did not give rise to behavioral alterations without CNO-mediated DREADD stimulation. Thus, the data in experiments 1 and 2 demonstrated that AAV injections per se did not alter behavioral performance in the NORT, either in NS or Ts65Dn mice.

These results show that hM3Dq-mediated enhancement of LC-NE activity in residual LC neurons of middle-aged Ts65Dn 
mice can exert significant beneficial effects on hyperactivity, center activity, and performance in the NORT.

\section{L-DOPS-mediated behavior}

In the current study, a second experiment was undertaken using pharmacological enhancement of NE neurotransmission without the potential altering effects of AAV injections, to determine whether the NE precursor L-DOPS could restore cognition in Ts65Dn mice. NS and Ts65Dn mice were treated with either vehicle or L-DOPS, which was administered three times per week for 2 weeks before behavioral testing and $5 \mathrm{~h}$ before the start of the behavioral task each day, similar to other previously published articles (Ouyang and Thomas, 2005; Kalinin et al., 2007). We wanted to first establish whether L-DOPS could facilitate memory for the familiar object in the novel object recognition task. An overall ANOVA revealed significant group differences in an overall comparison $\left(F_{(2,22)}=3.976 ; p=0.0361\right)$. NS mice treated with L-DOPS $(n=5)$ were not statistically significant from NS vehicletreated mice $(n=6)$ in terms of either percentage of time spent with the novel object ( $p=0.9526$ ) or DI ( $p=0.1159)$, demonstrating that this drug had no behavioral effects on NS mice (Fig. $4 B, C)$. Compared with NS mice, a post hoc analysis revealed that vehicle-treated Ts65Dn mice showed a significant impairment in their ability to detect the novel object ( $p=0.0245$; Fig. $4 B$ ). However, the inability of vehicle-treated Ts65Dn mice to detect the novel object was reversed by the NE prodrug L-DOPS, as L-DOPS-treated Ts65Dn mice spent significantly more time with the novel object than vehicle-treated Ts65Dn mice ( $p=0.0239$; Fig. 4B). However, there was no statistical significance between L-DOPS-treated Ts65Dn and NS mice, suggesting that L-DOPS corrected behavioral deficits in Ts65Dn mice $(p=0.8013)$. An overall ANOVA revealed significant group differences for DI as well (Fig. $4 C ; F_{(2,22)}=4.011 ; p=0.0343$ ). In a post hoc analysis (Tukey's test), Ts65Dn mice exhibited a significant preference for the familiar object as indicated by the negative DI value ( $p=$ 0.0235). However, upon treatment with L-DOPS, Ts65Dn mice were able to detect the novel object, as L-DOPS-treated Ts65Dn mice showed a significantly higher DI than vehicle-treated Ts65Dn mice ( $p=0.0231$ ), while L-DOPS-treated Ts65Dn mice were not significantly different from the NS mice ( $p=0.6423$ ).

Finally, it has been previously shown that the four-arm SAT is a measure of hippocampal function (Ragozzino et al., 1998), with fewer alternations indicative of poor cognition (Savage et al., 2003). When comparing overall alternation rates in this task in an overall ANOVA, we also found significant group differences for this task $\left(F_{(2,22)}=4.918 ; p=0.0167\right)$, and post hoc analysis revealed that NS mice had a significantly higher percentage of alternations than vehicle-treated Ts65Dn mice ( $p=0.0063)$, suggesting that hippocampal function is reduced in 12-monthold Ts65Dn mice compared with NS. However, no significant differences were observed when the L-DOPS and VEH groups of NS mice were compared ( $p=0.4128$ ). The alternation deficit was reversed by L-DOPS, with Ts65Dn L-DOPS mice making significantly more alternations than age-matched vehicle-treated Ts65Dn mice ( $p=0.0187$; Fig. $4 D)$. There was no significant difference between the NS vehicle-treated and Ts65Dn L-DOPStreated groups ( $p=0.8715$ ), suggesting that the drug treatment corrected spontaneous alternation deficits in Ts65Dn mice at this age. Our behavioral results collectively suggest that administering the systemic NE prodrug L-DOPS can improve hippocampal function in Ts65Dn mice, in at least two different hippocampaldependent behavioral tasks, and therefore extend the findings of previous studies regarding LC-enhancing drugs in DS mouse models.

\section{$\beta 1$ adrenergic receptor immunostaining}

After 2 weeks of vehicle or L-DOPS treatment, $\beta 1$ receptor immunostaining was examined in the hippocampus. Morphological assessment of the receptor immunostaining revealed that vehicle-treated NS and Ts65Dn mice had higher $\beta 1$ receptor staining density than the NS and Ts65Dn groups treated with L-DOPS (Fig. $5 C-F$ ). Increased $\beta 1$ receptor immunostaining was observed within neurons in the hilar region and in the granular cell layer of the dentate. An overall ANOVA of $\beta 1$ receptor staining density in the dentate revealed significant group differences $\left(F_{(2,21)}=29.16 ; p<0.0001\right)$. Post hoc analysis (Tukey's test) demonstrated that vehicle-treated NS mice exhibited significantly higher density of $\beta 1$ receptor staining in the dentate compared with L-DOPS-treated NS mice ( $p=0.0001$; Fig. $5 A$ ). Furthermore, vehicle-treated Ts65Dn mice had a significantly higher $\beta 1$ receptor staining density compared with L-DOPStreated Ts65Dn mice $(p<0.0001)$. Importantly, vehicle-treated Ts65Dn mice displayed a significantly higher $\beta 1$ receptor staining density than vehicle-treated NS mice $(p=0.0015)$, which may, at least partially, explain the behavioral deficits observed in vehicletreated Ts65Dn mice compared with age-matched NS mice. Collectively, these data demonstrate that the NE prodrug L-DOPS gives rise to a reduction in the expression of $\beta 1$ receptors in the hippocampus of both groups.

Finally, a PPMC correlation analysis revealed a significant correlation between hippocampal NE levels, measured using HPLC, and $\beta 1$ receptor staining density (Fig. $5 B ; p=0.019, R^{2}=$ $0.44)$. There were no group differences in terms of NE levels in the hippocampus due to high variability within the groups, even though a trend toward reduced NE levels was observed in the Ts65Dn saline-treated group (data not shown). We did not observe significant correlations between $\beta 1$ receptor density and the levels of other catecholamines in response to L-DOPS treatment (data not shown).

\section{Discussion}

Our findings are the first to demonstrate that hM3Dq/CNOmediated LC activation restores memory function in middleaged Ts65Dn mice. Artificially stimulating LC-NE function acutely via selective hM3Dq/CNO-mediated LC activation and systemically via the NE prodrug L-DOPS enhanced cognition in Ts65Dn mice in hippocampal-dependent behavioral tasks, including the NORT and the SAT. When comparing behavioral performance in the two experiments by group-to-group comparison (Figs. 3, 4), the AAV injections themselves did not produce any behavioral alterations in either Ts65Dn or NS mice. Ts65Dn mice undergo a progressive loss of LC-NE neurons, beginning at 6 months of age (Salehi et al., 2009; Lockrow et al., 2011), and the current work extended and confirmed these findings. Stimulation of the DREADD receptors with CNO also reduced hyperactivity in Ts65Dn mice, and increased time spent in the center in the spontaneous locomotion box, suggesting that hyperactivity and anxiety may have been corrected with the LC-enhancing DREADD activation. Further, double labeling using HA and TH antibodies confirmed efficient and selective transduction of DREADD receptors into LC-NE neurons, with an average of $98 \%$ coexpression of TH and the HA tag. Immunostaining of $\beta 1$ receptors confirmed an upregulation of noradrenergic receptor staining in Ts65Dn mice, which was corrected by long-term L-DOPS administration. 
Several pharmacological and genetic manipulations in rodents have linked NE production in the LC to hippocampal function. Mice deficient in dopamine- $\beta$ hydroxylase (D $\beta \mathrm{H}$ knock-out mice) exhibit memory retention deficits that can be reversed by treatment with the $\beta 1$ agonist xamoterol (Murchison et al., 2004). In humans with DS, the LC undergoes an accelerated and significant degeneration by as much as $60 \%$ compared with agematched non-DS brains (German et al., 1992). The LC-hippocampal NE circuit is important for blood-brain barrier integrity, regulating neuroinflammatory processes, and has direct effects on learning and memory (for review, see O'Donnell et al., 2012). It has been shown that the development of $\mathrm{AD}$ pathology is aggravated by LC-NE neurodegeneration (Chalermpalanupap et al., 2013), and we have reported similar findings regarding DS-AD neuropathology in the Ts65Dn mouse (Lockrow et al., 2011). In a recent study, Hammerschmidt et al. (2013) crossed $\mathrm{D} \beta \mathrm{H}$ knock-out mice with amyloid precursor protein (APP)/presenilin-1 (PS1) mice overexpressing mutant APP and PS1. They found that LC-NE loss in the $\mathrm{AD}$ mouse leads to greater deficits in hippocampal-dependent memory tasks, and that L-DOPS administration alleviated these effects, providing additional evidence for the important role of LC-NE neurons in neuropathology and memory deficits occurring both in idiopathic AD and in DS-AD. The current data extend the knowledge in this area by demonstrating that stimulation of remaining LC-NE neurons exerts powerful effects on behavior related to hippocampal function.

The findings presented here are the first to demonstrate that hM3Dq/CNOmediated LC activation can regulate cognition in the Ts65Dn mouse model of DS. Previously, our laboratory has shown that the loss of LC-NE can exacerbate cognitive impairment and neuropathology in Ts65Dn mice (Lockrow et al., 2011), suggesting a role for NE dysfunction in the accelerated neuropathology observed in Ts65Dn mice. We observed that artificially restoring LC-NE function via selective hM3Dq/CNO-mediated LC activation and via the NE prodrug L-DOPS enhanced hippocampal-dependent memory in Ts65Dn mice, both of which corroborate the findings of others demonstrating a role for NE in facilitating cognition (Salehi et al., 2006, 2009; Dang et al., 2014). Our group has recently shown that stimulation of hM3Dq DREADD receptors in the LC-NE neurons by systemic injection of the inert DREADD ligand CNO doubles the firing frequency of LC-NE neurons and facilitates cortical EEG changes (Vazey and Aston-Jones, 2014), suggesting that activation of

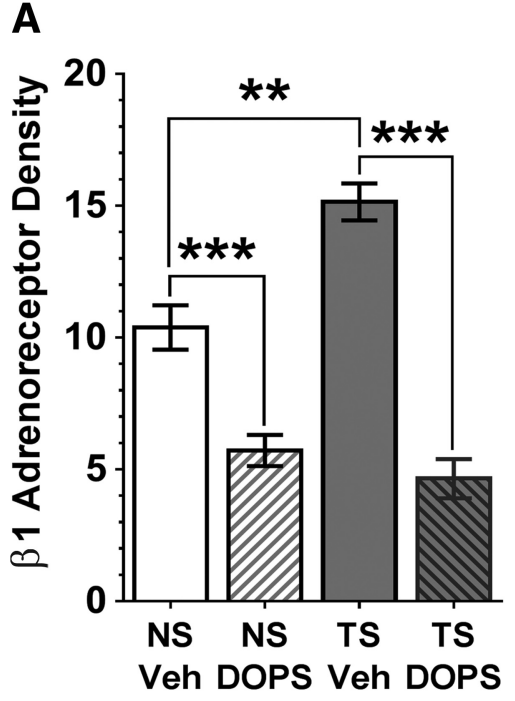

B
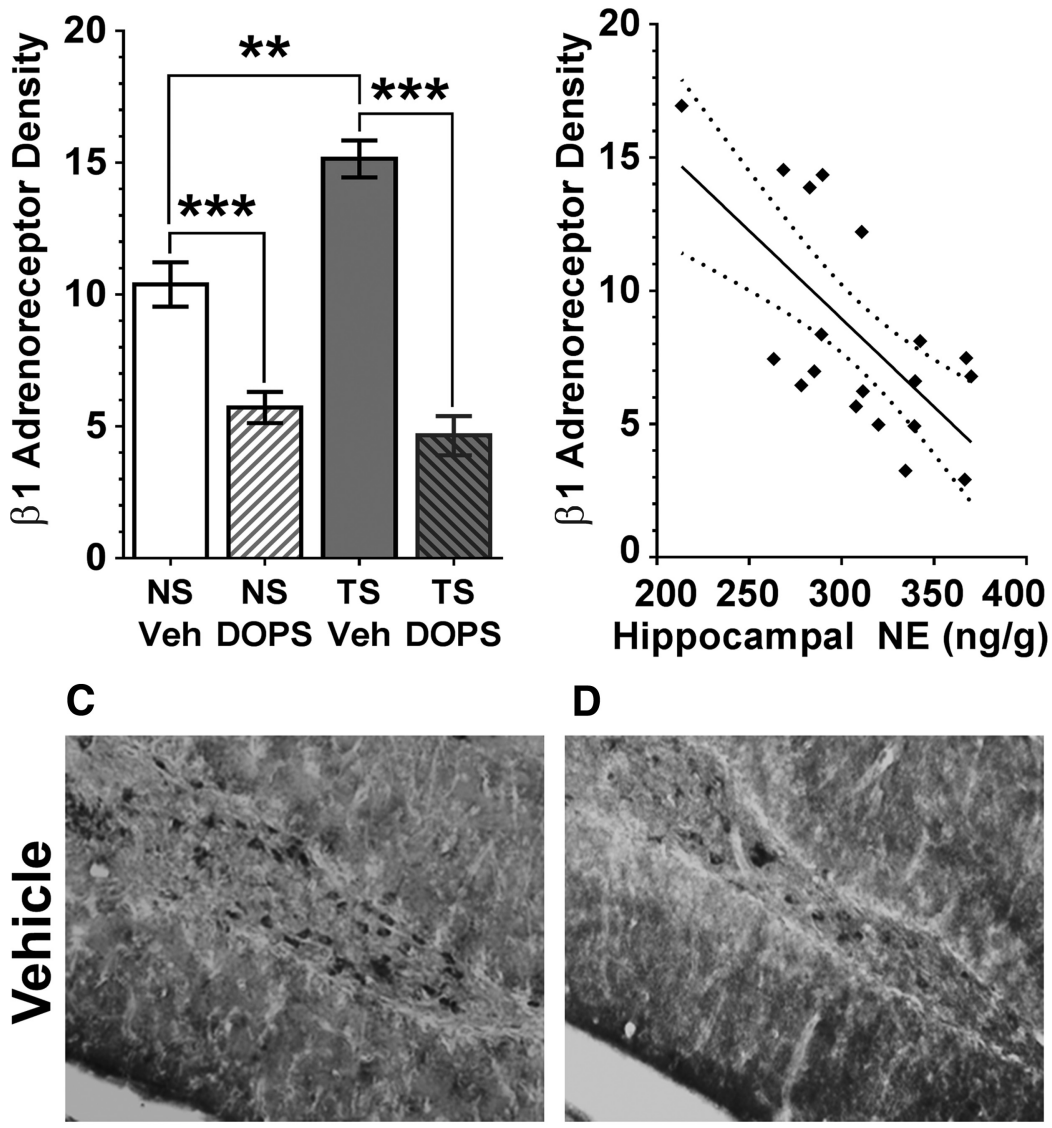

D
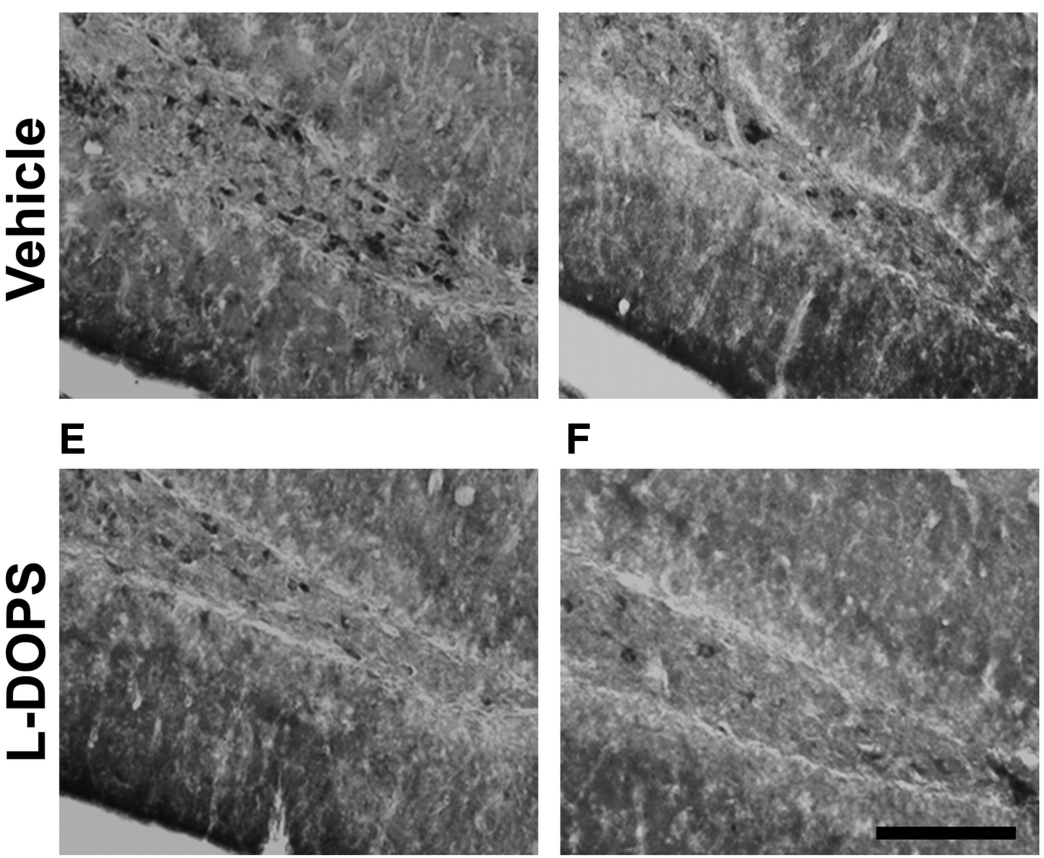

Normosomic (NS)
$\mathbf{F}$

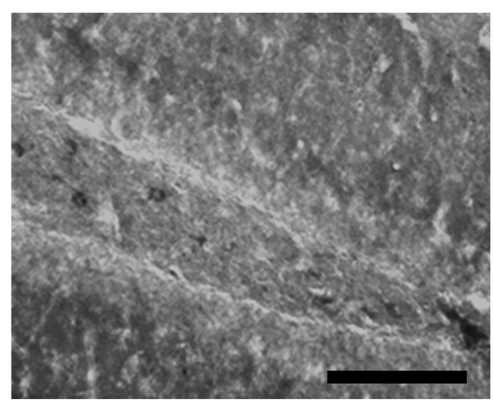

Ts65Dn (TS)

Figure 5. $\quad \beta 1$ receptor immunostaining. $\boldsymbol{A}$, Densitometry demonstrated overall differences in $\beta 1$ immunostaining among all four groups, and post hoc analysis showed that L-DOPS treatment gave rise to a significant reduction in staining density in both NS and Ts65Dn (TS) groups to comparable levels. Error bars represent the mean \pm SEM. $\boldsymbol{B}$, Correlation analysis of $\beta 1$ receptor staining and NE levels in the hippocampus revealed a significant correlation $\left(F=13.51, p=0.0019, R^{2}=0.44\right)$. NE concentration is represented as nanograms per gram for the amount of NE/wet weight of tissue in grams. Dotted lines represent the $90 \%$ confidence interval of the best fit line ( $n=20-25$ per plot). $C-F, \beta 1$ immunostaining in the dentate/hilar region of the hippocampus. Increased immunostaining was observed with neurons of the hilar region, as well as in the dentate granule layer in the Ts65Dn mice versus age-matched NS controls. Scale bar, $200 \mu \mathrm{m}$. L-DOPS treatment for 2 weeks reduced adrenergic receptor staining differences between the groups. ${ }^{* *} p<0.01 ;{ }^{* * *} p<0.001$.

hM3Dq receptors following CNO administration can drive LC neuronal firing rates. Vazey and Aston-Jones (2014) also found a close to $100 \%$ transduction efficiency by the same construct in LC neurons, corroborating the transduction efficiency observed in this study (Fig. 2H). Our results presented herein expand upon these studies by demonstrating that LC-NE activity driven by CNO-mediated hM3Dq stimulation affects both consolidation and retrieval of hippocampal-dependent memory in the Ts65Dn 
DS mouse model. The findings also demonstrate that AAVDREADD intracranial injections resulted in a nearly complete transduction of TH-positive LC neurons, suggesting that the PRSx8-hM3Dq-HA vector represents an effective method for assessing behavioral consequences of selectively stimulating or inhibiting LC neurons using the newly developed DREADD systems.

It has been shown that hippocampal NE plays an important role in the retrieval of contextual information in memory processing. Mice deficient in $\mathrm{D} \beta \mathrm{H}$ exhibit spatial and contextual retrieval deficits (Thomas and Palmiter, 1997). Furthermore, hippocampal infusions of the $\beta$ receptor agonist isoproterenol facilitates contextual fear memory in $\mathrm{D} \beta \mathrm{H}$-deficient mice, suggesting that activation of $\beta$ receptors in the hippocampus are necessary and sufficient for memory retrieval (Murchison et al., 2004), and may be one mechanism by which LC-NE stimulation via DREADD receptors enhanced memory in Ts65Dn mice. Short-term DREADD-CNO stimulation in this study is unlikely to elicit changes in immunostaining of $\beta 1$ receptors, contrary to the long-term administration of L-DOPS in the second, pharmacological, experiment (Fig. 5). The inability of Ts65Dn mice to retrieve information is supported by previous studies demonstrating that NE is necessary for hippocampal-dependent memory retrieval (Murchison et al., 2004; Zhang et al., 2013). The DREADD/CNO experiment further demonstrates that acute activation of a residual, albeit degenerating, LC-NE pathway, is sufficient to normalize deficits in hippocampal-dependent memory in Ts65Dn mice. This is supported by evidence that pharmacologically restoring NE levels in Ts65Dn mice and in Dbh-deficient mice enhances hippocampal-dependent memory (Salehi et al., 2009; Dang et al., 2014; Murchison et al., 2011). In addition to enhanced performance in the NORT, the LC-NE stimulation in Ts65Dn mice via CNO gave rise to increased time spent in the center and reduced hyperactivity in the spontaneous locomotion chamber. Reduced time spent in the center may be a reflection of anxiety as well as hyperactivity, which may lead to reduced attention and/or performance in memory tasks (Warner et al., 2014). Specifically, impaired executive function is closely connected to LC-NE degeneration (Vazey and Aston-Jones, 2012), and individuals with DS exhibit deficits in this cognitive domain (Kittler et al., 2008; Lanfranchi et al., 2010). Therefore, using NE-enhancing drugs for individuals with DS-AD may lead to significant improvement not only in memory, but also in anxiety- and attention-related behaviors. This is especially important since classic AD medications may be less effective in the treatment of DS-AD compared with idiopathic AD (Iulita et al., 2014), and there are currently no effective medications available to mediate cognition in DS patients.

As a second approach to demonstrate the importance of the LC-NE system in regulating hippocampal function in Ts65Dn mice, we used a systemic method that is more comparable to options available in the clinic. L-DOPS, currently pending Food and Drug Administration approval in the United States, is widely prescribed in Europe and Asia for neurogenic orthostatic hypotension to treat symptoms associated with Parkinson's disease and to reduce side effects from hemodialysis (Isaacson and Skettini, 2014). We reasoned that L-DOPS would enhance hippocampal function similar to measures observed with hM3Dq/CNOmediated LC activation in the first study, and long-term dosing may reduce pathological $\beta 1$ noradrenergic receptor expression in the hippocampus. Similar to acute regulation of the LC following hM3Dq/CNO-mediated LC activation, long-term systemic
L-DOPS treatment also enhanced cognition in the NORT in Ts65Dn mice. Specifically, Ts65Dn mice treated with L-DOPS showed a reversal in cognitive deficits in both the NORT and the spontaneous alternation task, suggesting that enhancing LC-NE signaling can facilitate hippocampal function in middle-aged Ts65Dn mice. Furthermore, L-DOPS treatment reduced $\beta 1$ NER expression. As expected following the LC-NE degeneration in the target region, Ts65Dn mice show an increase in $\beta 1$ NER in the hilar region of the hippocampus due to a progressive loss of LC-NE innervation (Salehi et al., 2009). Since $\beta 1$ receptor knockout mice exhibit impaired memory retrieval, an optimal expression level of these receptors may be necessary for performance in hippocampal-dependent behavioral tasks (Murchison et al., 2011), perhaps by regulating slow afterhyperpolarization to facilitate excitatory transmission, as suggested by others (Zhang et al., 2013). Understanding the cellular mechanisms downstream of $\beta 1$ receptor activation is necessary for facilitating hippocampal memory in aging Ts65Dn mice may enhance the discovery of novel drug targets for both the AD and DS-AD populations.

Collectively, our results suggest that artificially stimulating $\mathrm{LC}-\mathrm{NE}$ function in the short term via hM3Dq/CNO-mediated LC activation and in the long term via the NE prodrug L-DOPS enhanced cognition in middle-aged Ts65Dn mice. Our findings expand previous findings by us and others (Murchison et al., 2004, 2011; Salehi et al., 2009; Lockrow et al., 2011) suggesting that the LC-NE pathway is a plausible target for new therapeutic agents in treating DS-AD and idiopathic AD. This would represent an important therapeutic avenue, since DS-related dementia currently has no effective treatment (Nelson et al., 2005) and occurs with high incidence in the adult DS population. Utilizing DREADD technology enables the discrimination of neuronal contributions to complex behavior without actions on neighboring cells or peripheral systems. Our study provides direct evidence for the feasibility of DREADD receptor technology to explore the role of discrete neuronal populations in neurodegenerative disorders and to identify potential therapeutic agents.

\section{References}

Alexander GM, Rogan SC, Abbas AI, Armbruster BN, Pei Y, Allen JA, Nonneman RJ, Hartmann J, Moy SS, Nicolelis MA, McNamara JO, Roth BL (2009) Remote control of neuronal activity in transgenic mice expressing evolved G protein-coupled receptors. Neuron 63:27-39. CrossRef Medline

Armbruster BN, Li X, Pausch MH, Herlitze S, Roth BL (2007) Evolving the lock to fit the key to create a family of $\mathrm{G}$ protein-coupled receptors potently activated by an inert ligand. Proc Natl Acad Sci U S A 104:51635168. CrossRef Medline

Boger HA, Middaugh LD, Huang P, Zaman V, Smith AC, Hoffer BJ, Tomac AC, Granholm AC (2006) A partial GDNF depletion leads to earlier age-related deterioration of motor function and tyrosine hydroxylase expression in the substantia nigra. Exp Neurol 202:336-347. CrossRef Medline

Boger HA, Mannangatti P, Samuvel DJ, Saylor AJ, Bender TS, McGinty JF, Fortress AM, Zaman V, Huang P, Middaugh LD, Randall PK, Jayanthi LD, Rohrer B, Helke KL, Granholm AC, Ramamoorthy S (2011) Effects of brain-derived neurotrophic factor on dopaminergic function and motor behavior during aging. Genes Brain Behav 10:186-198. CrossRef Medline

Bramham CR, Bacher-Svendsen K, Sarvey JM (1997) LTP in the lateral perforant path is beta-adrenergic receptor-dependent. Neuroreport 8:719724. CrossRef Medline

Cass WA, Harned ME, Peters LE, Nath A, Maragos WF (2003) HIV-1 protein Tat potentiation of methamphetamine-induced decreases in evoked overflow of dopamine in the striatum of the rat. Brain Res 984:133-142. CrossRef Medline

Chalermpalanupap T, Kinkead B, Hu WT, Kummer MP, Hammerschmidt T, Heneka MT, Weinshenker D, Levey AI (2013) Targeting norepineph- 
rine in mild cognitive impairment and Alzheimer's disease. Alzheimers Res Ther 5:21. CrossRef Medline

Clark RE, Zola SM, Squire LR (2000) Impaired recognition memory in rats after damage to the hippocampus. J Neurosci 20:8853-8860. Medline

Dang V, Medina B, Das D, Moghadam S, Martin KJ, Lin B, Naik P, Patel D, Nosheny R, Wesson Ashford J, Salehi A (2014) Formoterol, a longacting $\beta 2$ adrenergic agonist, improves cognitive function and promotes dendritic complexity in a mouse model of Down syndrome. Biol Psychiatry 75:179-188. CrossRef Medline

Davisson MT, Schmidt C, Akeson EC (1990) Segmental trisomy of murine chromosome 16: a new model system for studying Down syndrome. Prog Clin Biol Res 360:263-280. Medline

Escorihuela RM, Fernández-Teruel A, Vallina IF, Baamonde C, Lumbreras MA, Dierssen M, Tobeña A, Flórez J (1995) A behavioral assessment of Ts65Dn mice: a putative Down syndrome model. Neurosci Lett 199:143146. CrossRef Medline

German DC, Manaye KF, White CL 3rd, Woodward DJ, McIntire DD, Smith WK, Kalaria RN, Mann DM (1992) Disease-specific patterns of locus coeruleus cell loss. Ann Neurol 32:667-676. CrossRef Medline

Glasson EJ, Dye DE, Bittles AH (2014) The triple challenges associated with age-related comorbidities in Down syndrome. J Intellect Disabil Res 58: 393-398. CrossRef Medline

Granholm AC, Sanders LA, Crnic LS (2000) Loss of cholinergic phenotype in basal forebrain coincides with cognitive decline in a mouse model of Down's syndrome. Exp Neurol 161:647-663. CrossRef Medline

Hammerschmidt T, Kummer MP, Terwel D, Martinez A, Gorji A, Pape HC, Rommelfanger KS, Schroeder JP, Stoll M, Schultze J, Weinshenker D, Heneka MT (2013) Selective loss of noradrenaline exacerbates early cognitive dysfunction and synaptic deficits in APP/PS1 mice. Biol Psychiatry 73:454-463. CrossRef Medline

Head E, Garzon-Rodriguez W, Johnson JK, Lott IT, Cotman CW, Glabe C (2001) Oxidation of Abeta and plaque biogenesis in Alzheimer's disease and Down syndrome. Neurobiol Dis 8:792-806. CrossRef Medline

Hunter CL, Bimonte HA, Granholm AC (2003a) Behavioral comparison of 4 and 6 month-old Ts65Dn mice: age-related impairments in working and reference memory. Behav Brain Res 138:121-131. CrossRef Medline

Hunter CL, Isacson O, Nelson M, Bimonte-Nelson H, Seo H, Lin L, Ford K, Kindy MS, Granholm AC (2003b) Regional alterations in amyloid precursor protein and nerve growth factor across age in a mouse model of Down's syndrome. Neurosci Res 45:437-445. CrossRef Medline

Hunter CL, Bachman D, Granholm AC (2004) Minocycline prevents cholinergic loss in a mouse model of Down's syndrome. Ann Neurol 56:675688. CrossRef Medline

Hwang DY, Carlezon WA Jr, Isacson O, Kim KS (2001) A high-efficiency synthetic promoter that drives transgene expression selectively in noradrenergic neurons. Hum Gene Ther 12:1731-1740. CrossRef Medline

Isaacson SH, Skettini J (2014) Neurogenic orthostatic hypotension in Parkinson's disease: evaluation, management, and emerging role of droxidopa. Vasc Health Risk Manag 10:169-176. CrossRef Medline

Iulita MF, Do Carmo S, Ower AK, Fortress AM, Aguilar LF, Hanna M, Wisniewski T, Granholm AC, Buhusi M, Busciglio J, Cuello AC (2014) Nerve growth factor metabolic dysfunction in Down's syndrome brains. Brain 137:860-872. CrossRef Medline

Kalinin S, Gavrilyuk V, Polak PE, Vasser R, Zhao J, Heneka MT, Feinstein DL (2007) Noradrenaline deficiency in brain increases beta-amyloid plaque burden in an animal model of Alzheimer's disease. Neurobiol Aging 28: 1206-1214. CrossRef Medline

Kato T, Karai N, Katsuyama M, Nakamura M, Katsube J (1987) Studies on the activity of L-threo-3,4-dihydroxyphenylserine (L-DOPS) as a catecholamine precursor in the brain. Comparison with that of L-dopa. Biochem Pharmacol 36:3051-3057. CrossRef Medline

Kaur G, Sharma A, Xu W, Gerum S, Alldred MJ, Subbanna S, Basavarajappa BS, Pawlik M, Ohno M, Ginsberg SD, Wilson DA, Guilfoyle DN, Levy E (2014) Glutamatergic transmission aberration: a major cause of behavioral deficits in a murine model of Down's syndrome. J Neurosci 34: 5099-5106. CrossRef Medline

Kittler PM, Krinsky-McHale SJ, Devenny DA (2008) Dual-task processing as a measure of executive function: a comparison between adults with Williams and Down syndromes. Am J Ment Retard 113:117-132. CrossRef Medline

Krinsky-McHale SJ, Devenny DA, Kittler P, Silverman W (2008) Selective attention deficits associated with mild cognitive impairment and early stage Alzheimer's disease in adults with Down syndrome. Am J Ment Retard 113:369-386. CrossRef Medline

Lanfranchi S, Jerman O, Dal Pont E, Alberti A, Vianello R (2010) Executive function in adolescents with Down syndrome. J Intellect Disabil Res 54: 308-319. CrossRef Medline

Lockrow JP, Fortress AM, Granholm AC (2012) Age-related neurodegeneration and memory loss in down syndrome. Curr Gerontol Geriatr Res 2012:463909. CrossRef Medline

Lockrow J, Prakasam A, Huang P, Bimonte-Nelson H, Sambamurti K, Granholm AC (2009) Cholinergic degeneration and memory loss delayed by vitamin E in a Down syndrome mouse model. Exp Neurol 216:278289. CrossRef Medline

Lockrow J, Boger H, Bimonte-Nelson H, Granholm AC (2011) Effects of long-term memantine on memory and neuropathology in Ts65Dn mice, a model for Down syndrome. Behav Brain Res 221:610-622. CrossRef Medline

Lockrow J, Boger H, Gerhardt G, Aston-Jones G, Bachman D, Granholm AC (2011) A noradrenergic lesion exacerbates neurodegeneration in a Down syndrome mouse model. J Alzheimers Dis 23:471-489. CrossRef Medline

Loy R, Koziell DA, Lindsey JD, Moore RY (1980) Noradrenergic innervation of the adult rat hippocampal formation. J Comp Neurol 189:699_ 710. CrossRef Medline

Mann DM, Yates PO, Marcyniuk B (1986) A comparison of nerve cell loss in cortical and subcortical structures in Alzheimer's disease. J Neurol Neurosurg Psychiatry 49:310-312. CrossRef Medline

Morris RG (2006) Elements of a neurobiological theory of hippocampal function: the role of synaptic plasticity, synaptic tagging and schemas. Eur J Neurosci 23:2829-2846. CrossRef Medline

Murchison CF, Zhang XY, Zhang WP, Ouyang M, Lee A, Thomas SA (2004) A distinct role for norepinephrine in memory retrieval. Cell 117:131-143. CrossRef Medline

Murchison CF, Schutsky K, Jin SH, Thomas SA (2011) Norepinephrine and ss(1)-adrenergic signaling facilitate activation of hippocampal CA1 pyramidal neurons during contextual memory retrieval. Neuroscience 181: 109-116. CrossRef Medline

Nawaratne V, Leach K, Suratman N, Loiacono RE, Felder CC, Armbruster BN, Roth BL, Sexton PM, Christopoulos A (2008) New insights into the function of M4 muscarinic acetylcholine receptors gained using a novel allosteric modulator and a DREADD (designer receptor exclusively activated by a designer drug). Mol Pharmacol 74:1119-1131. CrossRef Medline

Nelson L, Johnson JK, Freedman M, Lott I, Groot J, Chang M, Milgram NW, Head E (2005) Learning and memory as a function of age in Down syndrome: a study using animal-based tasks. Prog Neuropsychopharmacol Biol Psychiatry 29:443-453. CrossRef Medline

O’Donnell J, Zeppenfeld D, McConnell E, Pena S, Nedergaard M (2012) Norepinephrine: a neuromodulator that boosts the function of multiple cell types to optimize CNS performance. Neurochem Res 37:2496-2512. CrossRef Medline

Ouyang M, Thomas SA (2005) A requirement for memory retrieval during and after long-term extinction learning. Proc Natl Acad Sci U S A 102: 9347-9352. CrossRef Medline

Paxinos G, Franklin K (2004) The mouse brain in stereotaxic coordinates. San Diego, CA: Academic.

Pei Y, Dong S, Roth BL (2010) Generation of designer receptors exclusively activated by designer drugs (DREADDs) using directed molecular evolution. Curr Protoc Neurosci Chapter 4:Unit 4.33. CrossRef Medline

Ragozzino ME, Pal SN, Unick K, Stefani MR, Gold PE (1998) Modulation of hippocampal acetylcholine release and spontaneous alternation scores by intrahippocampal glucose injections. J Neurosci 18:1595-1601. Medline

Ruparelia A, Pearn ML, Mobley WC (2013) Aging and intellectual disability: insights from mouse models of Down syndrome. Dev Disabil Res Rev 18:43-50. CrossRef Medline

Salehi A, Delcroix JD, Belichenko PV, Zhan K, Wu C, Valletta JS, TakimotoKimura R, Kleschevnikov AM, Sambamurti K, Chung PP, Xia W, Villar A, Campbell WA, Kulnane LS, Nixon RA, Lamb BT, Epstein CJ, Stokin GB, Goldstein LS, Mobley WC (2006) Increased App expression in a mouse model of Down's syndrome disrupts NGF transport and causes cholinergic neuron degeneration. Neuron 51:29-42. CrossRef Medline

Salehi A, Faizi M, Colas D, Valletta J, Laguna J, Takimoto-Kimura R, Kleschevnikov A, Wagner SL, Aisen P, Shamloo M, Mobley WC (2009) 
Restoration of norepinephrine-modulated contextual memory in a mouse model of Down syndrome. Sci Transl Med 1:7ra17. CrossRef

Savage LM, Chang Q, Gold PE (2003) Diencephalic damage decreases hippocampal acetylcholine release during spontaneous alternation testing. Learn Mem 10:242-246. CrossRef Medline

Schliebs R, Arendt T (2011) The cholinergic system in aging and neuronal degeneration. Behav Brain Res 221:555-563. CrossRef Medline

Stanton PK, Sarvey JM (1985) Depletion of norepinephrine, but not serotonin, reduces long-term potentiation in the dentate gyrus of rat hippocampal slices. J Neurosci 5:2169-2176. Medline

Stefani MR, Gold PE (2001) Intrahippocampal infusions of k-ATP channel modulators influence spontaneous alternation performance: relationships to acetylcholine release in the hippocampus. J Neurosci 21:609614. Medline

Stoltzner SE, Grenfell TJ, Mori C, Wisniewski KE, Wisniewski TM, Selkoe DJ, Lemere CA (2000) Temporal accrual of complement proteins in amyloid plaques in Down's syndrome with Alzheimer's disease. Am J Pathol 156:489-499. CrossRef Medline

Thomas SA, Palmiter RD (1997) Disruption of the dopamine betahydroxylase gene in mice suggests roles for norepinephrine in motor function, learning, and memory. Behav Neurosci 111:579-589. CrossRef Medline

Vazey EM, Aston-Jones G (2012) The emerging role of norepinephrine in cognitive dysfunctions of Parkinson's disease. Front Behav Neurosci 6:48. CrossRef Medline

Vazey EM, Aston-Jones G (2014) Designer receptor manipulations reveal a role of the locus coeruleus noradrenergic system in isoflurane general anesthesia. Proc Natl Acad Sci U S A 111:3859-3864. CrossRef Medline

Warner G, Moss J, Smith P, Howlin P (2014) Autism characteristics and behavioural disturbances in $\sim 500$ children with Down's syndrome in England and Wales. Autism Res 7:433-441. CrossRef Medline

Wisniewski KE, Wisniewski HM, Wen GY (1985) Occurrence of neuropathological changes and dementia of Alzheimer's disease in Down's syndrome. Ann Neurol 17:278-282. CrossRef Medline

Zhang L, Ouyang M, Ganellin CR, Thomas SA (2013) The slow afterhyperpolarization: a target of $\beta 1$-adrenergic signaling in hippocampusdependent memory retrieval. J Neurosci 33:5006-5016. CrossRef Medline

Zigman WB (2013) Atypical aging in Down syndrome. Dev Disabil Res Rev 18:51-67. CrossRef Medline 